\title{
Chronic ethanol vapor exposure potentiates cardiovascular responses to acute stress in male but not in female rats
}

Paula C. Bianchi ${ }^{1,2,3^{*}}$ (D), Lucas Gomes-de-Souza ${ }^{1,2}$, Willian Costa-Ferreira ${ }^{1,2}$, Paola Palombo ${ }^{1,2}$,

Paulo E. Carneiro de Oliveira ${ }^{4}$, Sheila A. Engi ${ }^{3,5}$, Rodrigo M. Leão ${ }^{6}$, Cleopatra S. Planeta ${ }^{1,2}$, Carlos C. Crestani ${ }^{1,2}$ and Fabio C. Cruz 3,5

\begin{abstract}
Background: Ethanol use is related to a wide variety of negative health outcomes, including cardiovascular diseases. Stress is also involved in numerous pathologies, such as cardiovascular diseases and psychiatric disorders. Sexual dimorphism is an important factor affecting cardiovascular response and has been proposed as a potential risk factor for sex-specific health problems in humans. Here, we evaluated the effect of prolonged ethanol vapor inhalation on arterial pressure, heart rate, and tail skin temperature responses to acute restraint stress, investigating differences between male and female rats.

Methods: We exposed male and female Long-Evans rats to ethanol vapor for $14 \mathrm{~h}$, followed by ethanol withdrawal for $10 \mathrm{~h}$, for 30 consecutive days, or to room air (control groups). The animals underwent surgical implantation of a cannula into the femoral artery for assessment of arterial pressure and heart rate values. The tail skin temperature was measured as an indirect measurement of sympathetic vasomotor response.

Results: Chronic ethanol vapor inhalation reduced basal heart rate in both female and male rats. Sex-related difference was observed in the decrease of tail cutaneous temperature evoked by stress, but not in the pressor and tachycardiac responses. Furthermore, prolonged ethanol inhalation enhanced the blood pressure and heart rate increase caused by acute restraint stress in male, but not in female rats. However, no effect of chronic ethanol vapor was observed in the tail cutaneous temperature response to restraint in either sex.
\end{abstract}

Conclusion: Chronic ethanol vapor exposure increased the cardiovascular reactivity to stress in male, but not in female rats.

Keywords: Alcohol, Blood pressure, Heart rate, Restraint stress, Sex

\footnotetext{
* Correspondence: paula.cbianchi@gmail.com; paula.bianchi@unifesp.br

${ }^{1}$ Laboratory of Neuropsypharmacology, School of Pharmaceutical Sciences,

São Paulo State University (UNESP), Rod. Araraquara-Jaú km 1, Araraquara, SP

14801-902, Brazi

${ }^{2}$ Joint Graduate Program in Physiological Sciences UFSCar/UNESP, Rod.

Washington Luís km 235, São Carlos, SP 13565-905, Brazil

Full list of author information is available at the end of the article
}

(c) The Author(s). 2021 Open Access This article is licensed under a Creative Commons Attribution 4.0 International License, which permits use, sharing, adaptation, distribution and reproduction in any medium or format, as long as you give appropriate credit to the original author(s) and the source, provide a link to the Creative Commons licence, and indicate if changes were made. The images or other third party material in this article are included in the article's Creative Commons licence, unless indicated otherwise in a credit line to the material. If material is not included in the article's Creative Commons licence and your intended use is not permitted by statutory regulation or exceeds the permitted use, you will need to obtain permission directly from the copyright holder. To view a copy of this licence, visit http://creativecommons.org/licenses/by/4.0/. The Creative Commons Public Domain Dedication waiver (http://creativecommons.org/publicdomain/zero/1.0/) applies to the data made available in this article, unless otherwise stated in a credit line to the data. 


\section{Background}

Excessive ethyl alcohol (ethanol) consumption is related to a wide variety of negative health outcomes and premature deaths [1]. According to the World Health Organization, among worldwide ethanol-related deaths in 2016, 19\% were due to cardiovascular diseases [1]. Clinical and preclinical studies have demonstrated that alterations in contractile/relaxant properties of the vascular smooth muscle, changes in neuroendocrine function, impairment of baroreflex activity, and autonomic imbalance constitute important mechanisms underlying the negative cardiovascular effects of heavy ethanol consumption [1-7].

Stress is a complex and multidimensional phenomenon of great biological importance that requires an appropriate and coordinated set of physiological responses for the maintenance of homeostasis [8-11]. Restraint is one of the most commonly employed stressors to investigate stress-evoked behavioral and physiological changes in laboratory animals [12-14]. This model is characterized by unconditioned and unavoidable stress-elicited neuroendocrine and cardiovascular responses, the latter being characterized by sustained blood pressure and heart rate (HR) increases that last throughout the restraint period $[10,15,16]$. In addition, cutaneous vasoconstriction during restraint leads to a fall in the tail skin temperature [17-19].

Sexual dimorphism is an important factor affecting cardiovascular response induced by both stress and chronic ethanol access [20-27]. For example, susceptibility to hypertension in men is generally associated with increased vascular response to stress when compared to women [28]. In addition, preclinical results showed that females are more resistant than males to stress-induced cardiovascular disorders [20]. Regarding the association between ethanol and cardiovascular impairments, results have demonstrated that hypertensive effect of ethanol in men is manifested in a linear dose-dependent manner [29-31], whereas a slight protective effect of ethanol is observed in women at moderate doses [32-34]. Accordingly, studies in rodents demonstrated that high blood alcohol levels (BALs) induced by chronic ethanol consumption evoked hypertension, increased sympathetic neural activity, and enhanced baroreflex tachycardic response in males [3-5, 7], while effects considered protective to cardiovascular function were reported in females, including hypotension, increased cardiac parasympathetic dominance, and bradycardic reflex response [21, 35-38]. Regarding stress responses, decreased stress-evoked cardiovascular changes were reported following acute ethanol administration [39]. Nevertheless, the impact of chronic ethanol exposure in cardiovascular reactivity during aversive threats has never been reported.
In addition, despite the evidence of differences in cardiovascular changes related to chronic ethanol exposure between females versus males [40-46], a possible influence of sexual dimorphisms in the effect of ethanol on stress-evoked cardiovascular changes is unknown. Thus, the present study aimed to evaluate the effect of chronic ethanol vapor inhalation on blood pressure, HR, and tail skin temperature responses to acute stress, investigating differences between male and female rats.

\section{Methods \\ Animals}

We used 25 male and 27 female Long-Evans rats at post-natal day (PND 60), obtained from the animal breeding facility at the School of Pharmaceutical Sciences, São Paulo State University (UNESP) (Araraquara, SP, Brazil). These were housed in standard rat cages (plastic cages) in a temperature-controlled room at 24 ${ }^{\circ} \mathrm{C}$ in the Animal Facility of the Physic Institute of São Carlos, University of São Paulo (USP) (São Carlos, SP, Brazil). The animals used in this study were the same animals used in our previous work [21]. They were kept under a 12:12-h light-dark cycle (lights on between 7:00 $\mathrm{h}$ and 19:00 h) with food and filtered water ad libitum. Housing conditions and experimental procedures were carried out following protocols approved by the Ethical Committee for Use of Animal and Subjects of the Physic Institute of São Carlos-USP (approval\# 2014/01), which complies with Brazilian and international guidelines for animal use and welfare.

\section{Drugs and solutions}

Ethanol 95\% (Labsynth, Diadema, SP, Brazil) and Isoflurane, USP (99.9\% v.v). Tribromoethanol (Sigma-Aldrich, St. Louis, MO, USA) and Flunixine meglumine (Banamine $^{\oplus}$; Schering-Plough, Cotia, SP, Brazil) was dissolved in saline $(\mathrm{NaCl} 0.9 \%)$. Poly-antibiotic preparation (Pentabiotico $^{\oplus}$; Fort Dodge, Campinas, SP, Brazil) were used as provided.

\section{Ethanol vapor inhalation}

Animals were exposed to chronic intermittent ethanol vapor in an attempt to induce a state of ethanol dependence in rodents, which is characterized by the presence of withdrawal signs, tolerance, and negative emotional symptoms upon cessation of ethanol vapor exposure [47-52]. Furthermore, compared to other methods, ethanol vapor inhalation offers advantages to the ethanol researcher, including the circumvention of rodents' natural aversion to ethanol and the ease of maintenance of consistent BALs [47-52].

We adapted the protocol from Leão et al. [53]. Briefly, animals were housed in standard rat cages that were placed into separate sealed clear acrylic chambers $(n=4$ 
per chamber), where the animals were exposed to controlled ethanol vapor. Evaporated ethanol values were adjusted as necessary to maintain animal BALs in the 150-350 (mg/dl) range. Animals were exposed daily to ethanol vapor inhalation for $14 \mathrm{~h}$ (7 p.m. -9 a.m.) followed by $10 \mathrm{~h}$ of withdrawal (no ethanol vapor inhalation), for 30 days. Blood samples were collected every week to confirm BALs. We used the single tail tip amputation (1-2 mm length per single amputation) method to perform the blood draws. Other blood collections were performed by removing the scab. The data of BALs are described in our previous study [21]. Control animals were not exposed to ethanol vapor and were not submitted to the blood drawing procedure.

\section{Surgical preparation}

Animals were anesthetized with tribromoethanol (250 $\mathrm{mg} / \mathrm{kg}$, i.p.) and a polyethylene cannula (a 4-cm segment of PE-10 heat-bound to a $13-\mathrm{cm}$ segment of PE-50) (Clay Adams, Parsippany, NJ, USA) filled with a solution of heparin (50 UI/ml, Hepamax-S ${ }^{\circ}$, Blausiegel, Cotia, SP, Brazil) diluted in saline $(0.9 \% \mathrm{NaCl})$ was inserted into the abdominal aorta through femoral artery for cardiovascular recording. The catheter was tunneled under the skin and exteriorized on the animal's dorsum. After the surgery, rats were treated with a poly-antibiotic formulation containing streptomycins and penicillins $(560 \mathrm{mg} /$ $\mathrm{ml} / \mathrm{kg}$, i.m.) to prevent infection and flunixin meglumine $(0.5 \mathrm{mg} / \mathrm{ml} / \mathrm{kg}$, s.c. $)$ - a non-steroidal anti-inflammatory drug-for postoperative analgesia.

\section{Blood pressure and heart rate recording}

The catheter implanted into the femoral artery was connected to a pressure transducer (DPT100, Utah Medical Products Inc., Midvale, UT, USA). Pulsatile blood pressure was recorded using an amplifier (Bridge Amp, ML224, ADInstruments, Australia) and a digital acquisition board (PowerLab 4/30, ML866/P, ADInstruments, NSW, Australia). Mean arterial pressure (MAP) and HR values were derived from the pulsatile blood pressure recording.

\section{Tail skin temperature measurement}

The cutaneous temperature of the tail was recorded using a thermal camera (IRI4010, InfraRed Integrated Systems Ltd., Northampton, UK). The temperature was measured on five points of the animal's tail and the mean value was calculated for each recording $[19,54]$.

\section{Restraint stress}

For acute restraint stress, each rat was placed in a plastic cylindrical restraint tube (diameter $6.5 \mathrm{~cm}$, length 15 $\mathrm{cm})$, ventilated by holes $(1 \mathrm{~cm}$ diameter $)$ that made up approximately $20 \%$ of the tube surface. Restraint lasted
30 min [54, 55], and immediately after the end of the stress exposure, rats were returned to their home cages. Each rat was submitted to only one session of restraint in order to avoid habituation $[56,57]$.

\section{Experimental protocols}

Different sets of female and male animals were randomly allocated in four experimental groups: (i) female control, whose animals were kept in their home cage without ethanol vapor exposure $(n=8)$; (ii) female ethanol vapor, whose animals were submitted to ethanol vapor chamber daily $(n=9)$; (iii) male control, whose animals were kept in their home cage without ethanol vapor exposure $(n=5)$; and (iv) male ethanol vapor, whose animals were submitted to ethanol vapor chamber daily $(n=9)$. A schematic representation of the experimental design is presented in Fig. 1. First, animals were exposed to intermittent ethanol vapor for 4 weeks. Blood samples were collected every week to confirm BALs. Twenty-four hours after the last ethanol vapor exposure day, animals in all experimental groups were subjected to surgical preparation. The next day, rats were brought to the experimental room in their own home cages. Rats were allowed $1 \mathrm{~h}$ to adapt to the conditions of the experimental room, such as sound and illumination, before starting arterial pressure and HR recording. The experimental room was temperature controlled $\left(25^{\circ} \mathrm{C}\right)$ and was acoustically isolated from the other rooms. Cardiovascular recording of MAP and HR of freely moving rats began at least $30 \mathrm{~min}$ before the onset of the restraint and was performed throughout the session of stress. The tail skin temperature was measured 10,5 , and $0 \mathrm{~min}$ before the restraint for baseline values and at $5,10,15,20,25$, and 30 min during restraint $[16,19]$. At the end of the experiment, the rats were anesthetized with isoflurane inhalation and decapitated.

\section{Data analysis}

Basal values of MAP, HR, and cutaneous temperature were evaluated by two-way ANOVA models, using sex and vapor as independent factors, and the average of the baseline measurements as a dependent variable.

The comparisons between the average values of MAP, $\mathrm{HR}$, and cutaneous temperature values during the prestress period (basal) and restraint stress session were conducted using three-way mixed ANOVA models, with sex and vapor as between-subject factors and time (basal $x$ stress) as a repeated-measure factor.

The time-course curves of MAP, HR, and cutaneous temperature during the stress session were evaluated by generalized estimation equation (GEE) model with sex and vapor as between-subject factors and time of stress exposure as a repeated-measure factor. GEE is a semiparametric model that evaluates longitudinal data that 


\section{Ethanol vapor inhalation}

\section{Surgical \\ preparation}

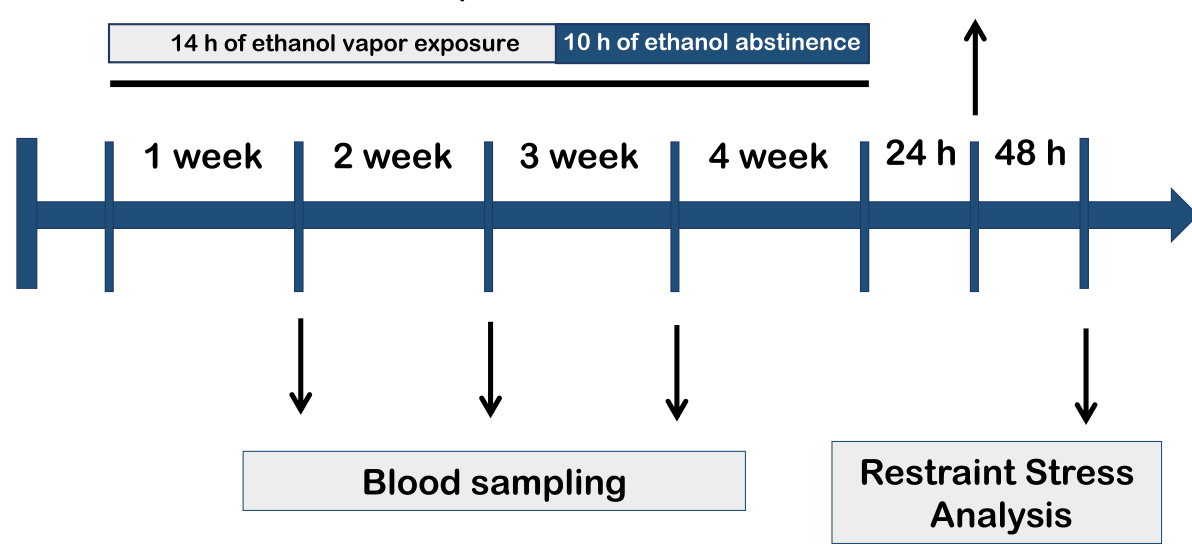

Fig. 1 Experimental design schematic representation. Female and male rats were submitted to daily sessions of ethanol vapor inhalation for $14 \mathrm{~h}$ (7 p.m. to 9 a.m.) followed by a 10-h withdrawal (no ethanol vapor inhalation) to evaluate chronic ethanol vapor exposure effects on cardiovascular parameters. Blood samples $(100 \mu \mathrm{l})$ were collected from the tip of the rat tail every week. Twenty-four hours after the last ethanol vapor exposure, we subjected all experimental groups to surgical preparation. Two days later, we performed cardiovascular measurements during basal and stress conditions (for details, see the description of "Experimental protocols" in the text)

displays advantages when compared to repeated measures ANOVA. Contrary to ANOVA, GEE can be used when normality assumption is violated, and it achieves higher power with smaller sample sizes $[58,59]$. GEE models were estimated using the robust estimator $(\mathrm{Hu}-$ ber-White estimator) and a first-order autoregressive correlation matrix structure. When main effects of time, sex, or vapor were detected, data were submitted to contrast analysis with Bonferroni adjustment for multiple comparisons. When two- or three-way interactions were detected, data from different experimental groups (vapor or sex) were analyzed separately. For example, GEE detected a statistically significant interaction between sex and time for tail temperature. Therefore, as a subsequent step, data were evaluated using two GEE models: one evaluating the effect of time on males and the other on females.
ANOVA analysis was conducted on GraphPad Prism 8.0.2 software and GEE analysis was conducted on the software SPSS v. 20. For all analysis, the adopted statistical significance level $(\alpha)$ was 0.05 .

\section{Results}

Effects of ethanol vapor exposure on basal values of arterial pressure, heart rate, and tail skin temperature Figure 2 depicts the mean \pm standard error of mean (SEM) of MAP, HR, and tail temperature during basal period in female and male rats. Analysis of MAP indicated no significant effect for $\operatorname{sex}\left(F_{(1,27)}=1.12, p>\right.$ $0.05)$, vapor $\left(F_{(1,27)}=0.21, p>0.05\right)$, or interaction between factors $\left(F_{(1,27)}=0.06, p>0.05\right)$ (Fig. 2a). Analysis of HR revealed a main effect of vapor $\left(F_{(1,27)}=5.24, p\right.$ $<0.05)$, with no effect for $\operatorname{sex}\left(F_{(1,27)}=0.09, p>0.05\right)$, or interaction between factors $\left(F_{(1,27)}=0.13, p>0.05\right)$

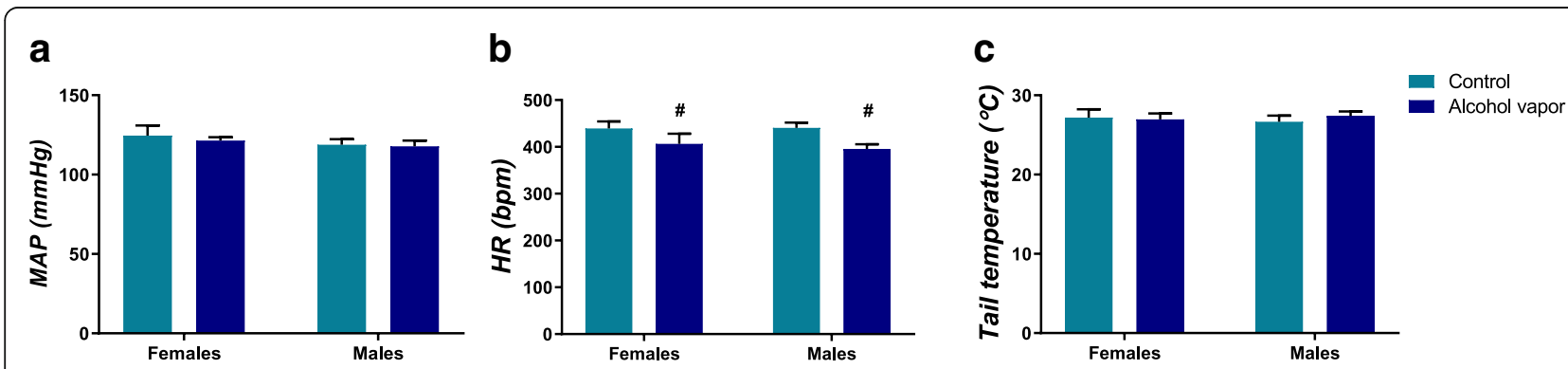

Fig. 2 Values of a mean arterial pressure (MAP), b heart rate (HR), and c tail skin temperature in female and male control rats (light blue bars) or rats that were submitted to ethanol vapor exposure (dark blue bars). The bars represent mean \pm SEM ( $n=5-9$ per group). Two-way ANOVA. The number sign indicates the main effect of vapor, $p<0.05$ 
(Fig. 2b). No significant effects of $\operatorname{sex}\left(F_{(1,40)}=0.005, p\right.$ $>0.05)$, vapor $\left(F_{(1,40)}=0.10, p>0.05\right)$, or interaction between factors $\left(F_{(1,40)}=0.34, p>0.05\right)$ were observed for tail skin temperature (Fig. 2c). In summary, the analysis of basal parameters showed that alcohol vapor exposure decreased HR in females and males, when compared to control groups, with no alteration of MAP and tail skin temperature.

\section{Effects of ethanol vapor exposure on cardiovascular responses to acute restraint stress}

Independently of sex or treatment, acute restraint stress increased MAP $\left(F_{(1,54)}=2037, p<0.0001\right)$ and HR $(F$ $(1,29)=1283, p<0.0001)$ and decreased tail cutaneous temperature $\left(F_{(1,43)}=25.14, p<0.0001\right)$, as revealed by a significant effect of time (basal $\times$ stress). Thus, these alterations reflect the physiological changes promoted by restraint stress.

During restraint stress, GEE analysis of MAP detected significant effects of sex, treatment, and time, as well as significant interactions sex $x$ time; vapor $\times$ time; and $\operatorname{sex} \times$ vapor $\times$ time (Table 1$)$. Subsequent analyses revealed a significant effect of sex in the group treated with vapor $(b=-6.48, p<0.05)$, but not in the control group $(b=-0.29, p>0.05)$. Furthermore, a significant effect of treatment was detected in males $(b=7.38, p<0.002)$, but not in females $(b=0.85, p>0.05)$. Taken together, the data indicates that chronic ethanol vapor inhalation potentiates the effect of acute stress on MAP in male, but not in female rats (Fig. 3).

For HR, GEE detected a main effect of time and significant interactions sex $\times$ time; vapor $\times$ time; and sex $\times$ vapor $\times$ time (Table 1 ). In Table 2 , we presented all the significant effects of time revealed by Bonferroni pairwise comparisons. Considering the data present in Fig. 3 with the results of statistical analysis, we can conclude that males exposed to ethanol vapor exhibit considerable variation of HR during restraint, when compared to females and male control group. In this regard, male vapor group showed an increase on tachycardia response, which was maintained until the last $10 \mathrm{~min}$ of stress session.

For tail temperature, GEE detected a significant main effect of time and an interaction sex $\times$ time (Table 1 ). Subsequent analysis revealed a significant effect of time in both males $\left(W_{(6)}=47.45, p<0.001\right)$ and females $\left(W_{(6)}=20.66, p<0.05\right)$. Pairwise comparisons showed that females displayed decreased tail temperature only in the first $5 \mathrm{~min}$ of restraint, whereas males displayed decreased temperature throughout the stress session (Fig. $3)$. This result indicates an immediate decrease in cutaneous temperature, which was sustained throughout the stress period in females, whereas males showed a more
Table 1 GEE (generalized estimation equation) model with blood pressure, heart rate, or tail temperature as the dependent variable, and sex, vapor condition, and time as independent factors

\begin{tabular}{|c|c|c|c|c|}
\hline Variables in the model & $w$ & $g l$ & $p$ & \\
\hline \multicolumn{5}{|l|}{ Blood pressure } \\
\hline Sex & 4.996 & 1 & 0.025 & * \\
\hline Vapor condition & 5.795 & 1 & 0.016 & * \\
\hline Time & 806.670 & 14 & $<0.001$ & * \\
\hline Sex $\times$ vapor & 3.086 & 1 & 0.079 & \\
\hline Sex $\times$ time & 155.382 & 14 & $<0.001$ & * \\
\hline Vapor $\times$ time & 42.638 & 14 & $<0.001$ & * \\
\hline Sex $\times$ vapor $\times$ time & 96.417 & 14 & $<0.001$ & * \\
\hline \multicolumn{5}{|l|}{ Heart rate } \\
\hline Sex & 0.167 & 1 & 0.683 & \\
\hline Vapor condition & 1.304 & 1 & 0.253 & \\
\hline Time & 447.653 & 14 & $<0.001$ & * \\
\hline Sex $\times$ vapor & 0.003 & 1 & 0.955 & \\
\hline Sex $\times$ time & 116.907 & 14 & $<0.001$ & * \\
\hline Vapor $\times$ time & 88.871 & 14 & $<0.001$ & * \\
\hline Sex $\times$ vapor $\times$ time & 62.33 & 14 & $<0.001$ & * \\
\hline \multicolumn{5}{|l|}{ Tail temperature } \\
\hline Sex & 0.854 & 1 & 0.355 & \\
\hline Vapor condition & 0.033 & 1 & 0.857 & \\
\hline Time & 42.697 & 6 & $<0.001$ & * \\
\hline Sex $\times$ vapor & 0.195 & 1 & 0.659 & \\
\hline Sex $\times$ time & 14.260 & 6 & 0.027 & * \\
\hline Vapor $\times$ time & 2.746 & 6 & 0.840 & \\
\hline Sex $\times$ vapor $\times$ time & 6.353 & 6 & 0.385 & \\
\hline
\end{tabular}

gradual decline in cutaneous temperature over the entire stress session. Nevertheless, analysis did not indicate an effect of ethanol vapor in restraint-evoked skin temperature changes in either female or male animals.

\section{Discussion}

Present findings provide evidence of the effects of chronic ethanol vapor exposure on cardiovascular function during acute restraint stress in female and male rats. Our main findings were as follows: (i) females and males exposed to ethanol vapor presented a decrease in basal HR when compared to control groups; (ii) sex-related difference was observed in the time-course of decrease in the cutaneous temperature under stress condition; (iii) chronic ethanol vapor enhanced the MAP and tachycardiac response caused by acute restraint stress in males, but not in females; and (iv) chronic ethanol vapor did not change the tail cutaneous temperature response to acute restraint stress in either sex. 

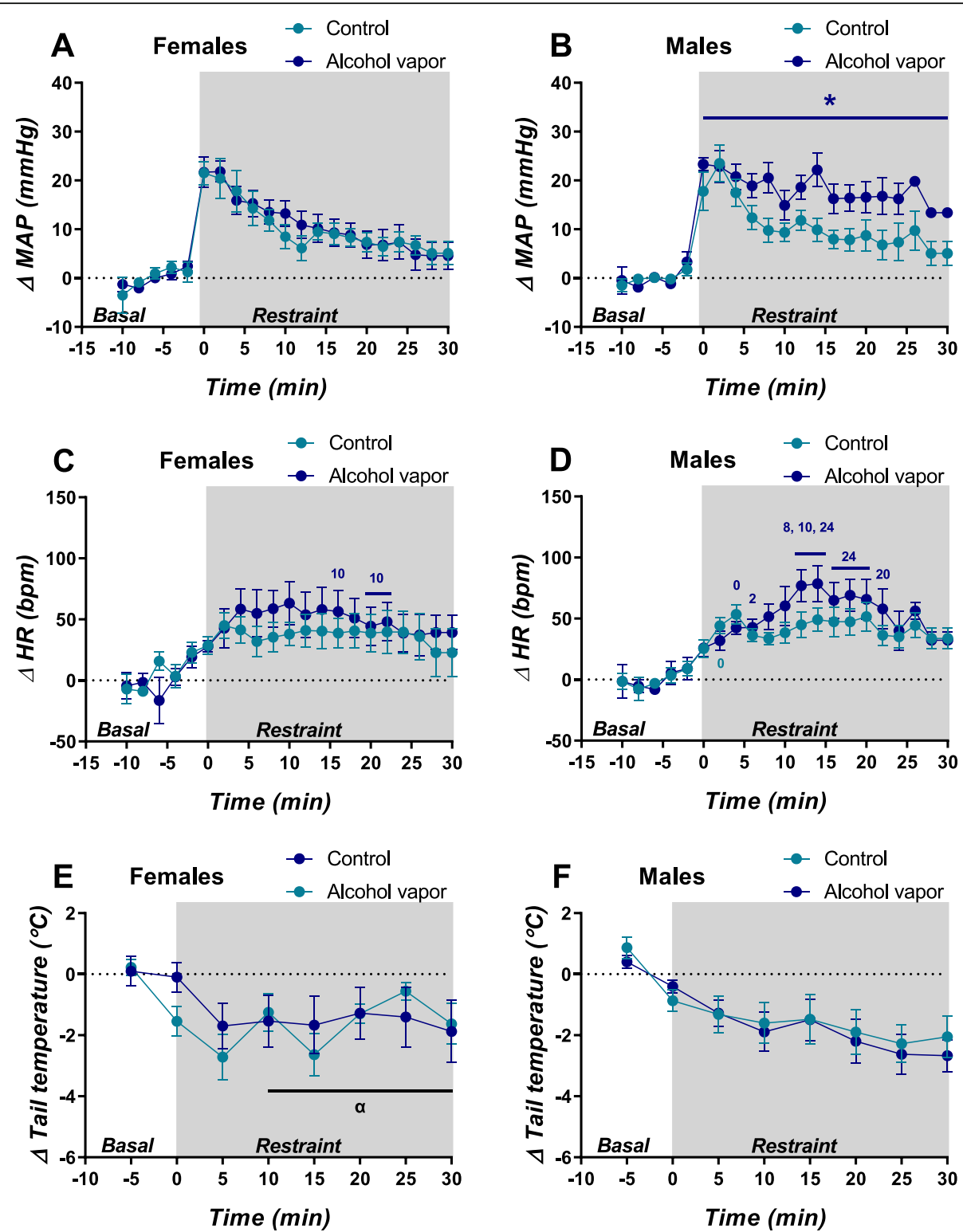

Fig. 3 Time-course curves of mean arterial pressure (MAP), heart rate (HR), and tail skin temperature (tail temperature) during pre-stress period (basal) and restraint stress session (restraint, shaded area) in females (left) and males (right) from control (light blue lines) or ethanol vapor (dark blue lines) groups. Circles represent the mean and bars the SEM ( $n=5-9$ per group). Generalized estimation equations followed by Bonferroni multiple comparisons. $\left(^{*}\right)$ Different to male control group, $p<0.05$; (0) different to time 0 of the same group, $p<0.05$; (2) different to time 2 of the same group, $p<0.05$; (8) different to time 8 of the same group, $p<0.05$; (10) different to time 10 of the same group, $p<0.05$; (24) different to time 24 of the same group, $p<0.05$; (20) different to time 20 of the same group, $p<0.05$. (a) Different to male groups, $p<0.05$

Alcohol dependence is a chronic relapsing disorder characterized by frequent episodes of intoxication, preoccupation with alcohol, use of alcohol despite adverse consequences, compulsion to seek and consume alcohol, loss of control in limiting alcohol intake, and emergence of a negative emotional state in the absence of the drug [60-62]. In our study, we exposed rats to chronic intermittent alcohol vapor to model the human condition in which alcohol exposure occurs in a series of extended exposures followed by periods of withdrawal. Previous studies using the chronic intermittent alcohol vapor model showed that motivational symptoms of dependence are present in rodents at acute withdrawal time points, as evidenced by increased anxiety-like behavior, increased alcohol drinking (i.e., escalation of ethanol self-administration), and increased willingness to work for alcohol, revealing alcohol's negative reinforcing properties [47, 63-66].

Excessive alcohol consumption is related to a wide variety of negative health outcomes, such as cardiovascular 
Table 2 Summary of Bonferroni pairwise comparison of heart rate $(H R)$ during restraint stress

\begin{tabular}{|c|c|c|c|}
\hline Group & Bonferroni comparison & $p$ & \\
\hline Female vapor & Time $10 \times$ time 16 & .000 & ${ }^{*} \uparrow$ \\
\hline Female vapor & Time $10 \times$ time 20 & .000 & ${ }^{*} \downarrow$ \\
\hline Female vapor & Time $10 \times$ time 22 & .000 & ${ }^{*} \downarrow$ \\
\hline Male control & Time $0 \times$ time 2 & .014 & $* \uparrow$ \\
\hline Male vapor & Time $2 \times$ time 6 & .000 & $* \uparrow$ \\
\hline Male vapor & Time $8 \times$ time 12 & .000 & $* \uparrow$ \\
\hline Male vapor & Time $8 \times$ time 14 & .001 & $* \uparrow$ \\
\hline Male vapor & Time $10 \times$ time 12 & .000 & $* \uparrow$ \\
\hline Male vapor & Time $10 \times$ time 14 & .000 & $* \uparrow$ \\
\hline Male vapor & Time $12 \times$ time 24 & .000 & ${ }^{*} \downarrow$ \\
\hline Male vapor & Time $14 \times$ time 24 & .000 & $*^{*} \downarrow$ \\
\hline Male vapor & Time $16 \times$ time 24 & .000 & ${ }^{*} \downarrow$ \\
\hline Male vapor & Time $18 \times$ time 24 & .000 & $*^{*} \downarrow$ \\
\hline Male vapor & Time $18 \times$ time 28 & .026 & $* \downarrow$ \\
\hline Male vapor & Time $18 \times$ time 30 & .026 & ${ }^{*} \downarrow$ \\
\hline Male vapor & Time $20 \times$ time 22 & .010 & ${ }^{*} \downarrow$ \\
\hline Male vapor & Time $20 \times$ time 24 & .000 & ${ }^{*} \downarrow$ \\
\hline Male vapor & Time $26 \times$ time 28 & .004 & ${ }^{*} \downarrow$ \\
\hline Male vapor & Time $26 \times$ time 30 & .004 & ${ }^{*} \downarrow$ \\
\hline
\end{tabular}

Up or down arrows indicate increase or decrease, respectively ${ }^{*} p<0.05$

diseases [1]. An association between chronic ethanol consumption and hypertension in males is well documented $[2-7,67]$. However, we did not observe alterations in MAP values, neither in males nor females. As demonstrated previously by our group [21], 4 weeks of ethanol vapor exposure was not enough to promote an increase in basal blood pressure in male rats. Previous studies have provided evidence that long-term ethanol exposure (e.g., 6,8 , or 12 weeks) is required to induce hypertension in males with BAL levels (100 to $300 \mathrm{mg} / \mathrm{dl}$ ) reached during ethanol inhalation $[2,5,67,68]$. In addition, different from other models of chronic forced ethanol exposure, such as liquid diet or ethanol in drinking water, the ethanol vapor is an intermittent model of ethanol access. In agreement with our results, Engi et al. [69] showed that 6 weeks of intermittent voluntary ethanol consumption did not induce an increase in blood pressure in male rats.

We observed decreased basal HR values in females and males exposed to ethanol vapor. The resting bradycardia effect of ethanol in females was described by other authors [21, 70-72] and might be followed by reductions in cardiac output and contractile force. For example, El-Mas and colleagues [70, 71] showed that females exposed to ethanol presented upregulation of cardiac nitric oxide synthase, which resulted in reductions of cardiac output. Further, Duan et al. [72] observed that ethanol metabolic product acetaldehyde induced cardiac contractile depression in females. Another explanation for the decrease in HR could be related to enhanced cardiac parasympathetic activity, which was observed in our previous study in females exposed to alcohol vapor [21]. In addition, it was demonstrated that decreases in basal HR are associated with inadequate tissue perfusion, arrhythmias, higher mortality, and sudden death $[73,74]$. Although previous studies did not report resting bradycardia in male rodents [2, 4, $5,7,21]$, similar mechanisms and consequences to those identified in females might be related to the HR decrease identified in the present study in males.

Our findings are in line with previous studies that reported blood pressure and HR increases, and decrease in the skin temperature as physiological changes during restraint stress $[10,16,18,19,75-77]$. However, in contrast to other authors $[22,23]$, we did not observe an influence of sex on MAP and HR during the stress session. Comparing the responses of males and females under immobilization stress, Anishchenko et al. [22] observed higher amplitude and duration of MAP elevation in males and a severe tachycardia in females. Another study, using spontaneously hypertensive rats, showed a greater change in MAP in response to restraint (60 min) in males, but not in females [23]. Nevertheless, we observed a sex-related difference in the cutaneous vasoconstriction response under stress conditions. In this regard, we observed that females presented an initial decrease in cutaneous temperature, which was sustained across stress exposure, whereas males showed a more gradual decline in cutaneous temperature over the entire stress session.

This sex-related effect on sympathetic vasomotor response in cutaneous bed can be related to ovarian hormones. For instance, Zhen and colleagues [78] reported that under adrenergic nerve stimulation, arteries from females were less responsive than arteries from male rats. They also observed that this sex difference was abolished after ovariectomy of the females but not after orchidectomy of the males [78], suggesting that circulating ovarian hormones inhibits sympathetically mediated vasoconstriction. In addition, a vasodilator effect of estrogens has been reported, which is mediated by rapid stimulation of endothelial nitric oxide synthase (eNOS), via membrane-associated estrogen receptors (ERs), increasing nitric oxide (NO) production [46, 79-81]. Considering these effects, estrogen could mediate the sexual differences on hemodynamic adjustments during aversive threats.

Although ethanol exposure did not change the basal MAP in male rats, chronic ethanol vapor inhalation potentiated the effect of acute stress on MAP in males, but not in females. The arterial pressure rise during stress is 
mediated by an increase in vascular sympathetic tone and activation of $\alpha_{1}$-adrenoreceptors in vascular smooth muscle $[82,83]$. In this sense, a sympathoexcitatory effect of ethanol in male rats was described in numerous studies [4, 5, 7, 67, 84, 85]. For example, Russ and colleagues [5] showed that chronic ethanol increased, via central nervous system modulation, the basal firing rate of sympathetic nerve fibers. They also observed that the sympathetic nervous activity was increased prior to the development of hypertension in males [5]. In addition, higher levels of plasma concentrations of adrenaline and noradrenaline $[6,86]$, as well as enhanced vascular reactivity to $\alpha_{1}$-adrenoceptor agonists [87-90] were observed in male rats chronically treated with ethanol. In this regard, Stewart and Kennedy [89] showed an ethanol-associated increase in the maximal contractile response to phenylephrine in endothelium-denuded preparations of male, but not of female rats. Thus, it is possible that the initial vasodilatory effect of ethanol [91, 92] is completely suppressed by increased sympathetic nervous activity in males $[5,93]$. Taken together, these results could explain the increase in cardiovascular stress reactivity in male, but not in female rats observed in the present study.

The exacerbated increase in MAP in male rats exposed to chronic ethanol vapor was accompanied by an enhanced tachycardia response. Cardiac sympathetic blockers abolish tachycardia response evoked by stress, whereas cardiac parasympathetic blocker increases it $[15,77,82,83]$. These results demonstrated that both sympathetic and parasympathetic outflows to the heart are activated during stress. Thus, an increase in restraint-evoked HR rise following ethanol exposure may result from a facilitation of cardiac sympathetic response or inhibition of parasympathetic activity in males. In this sense, the sympathoexcitatory effect of ethanol stated above might also mediate the enhanced tachycardia to stress in addition to the change on pressor response. Although previous results from our group did not indicate changes in parasympathetic activity in male rats subjected to chronic ethanol inhalation [21], we cannot exclude the possibility of an involvement of inhibition of this autonomic branch in facilitation of tachycardia to restraint.

There is significant report evidence that ethanol withdrawal is characterized by elevated glucocorticoid levels that reflect increased hypothalamic-pituitary-adrenal (HPA) axis activity, as well as by increased activity of the sympathetic nervous system, which produces significant physiological symptoms, including tachycardia, elevated blood pressure, and body temperature dysregulation [94-96]. In this regard, studies have demonstrated that dependence models involving chronic intermittent alcohol exposure constitute potent stressors, as evidenced by initial activation and subsequent dysregulation of HPA axis activity [94, 97]. Furthermore, it was demonstrated that the post-dependent state in laboratory animals is characterized by a persistently upregulated behavioral sensitivity to stress [98-100]. Clinical studies demonstrated that despite the fact that autonomic-related symptoms can return to normal in a few days during acute alcohol withdrawal in alcoholics, some cardiovascular changes may persist, especially when assessed following a stress challenge [101-103]. Our results in male rats are in accordance with these findings, since the intermittent alcohol vapor exposition intensified the cardiovascular stress reactivity.

Differently from males, no effect of chronic ethanol vapor was observed on MAP or HR values during restraint stress in females. Sexual dimorphism influences the cardiovascular effects promoted by chronic ethanol exposure [21, 89], which may impact the autonomic and hemodynamic stress responses. In contrast to sympathoexcitatory effects of ethanol in males, an increase in cardiac parasympathetic dominance has been observed in females following long-term ethanol access [21, 36, 37, 104, 105]. In fact, as stated above, we demonstrated increased cardiac parasympathetic activity in female but not in male rats exposed to chronic ethanol vapor inhalation [21]. Furthermore, other studies observed that this effect on cardiac vagal tone was estrogen-dependent [36, 104, 105]. For example, El-mas and Abdel-rahman [36] showed that the parasympathetic overactivity induced by chronic ethanol was exacerbated in estrogen-replaced ovariectomized rats, when compared to ovariectomized ones. Accordingly, El-mas and Abdel-rahman [37] observed that ovariectomized rats exposed to ethanol presented enhanced sympathetic activity as indicated by significant increases in plasma norepinephrine levels. Considering the importance of baroreflex response for the control of autonomic activity [106], we previously observed that only females exposed to alcohol vapor had increased baroreflex bradycardic response [21]. Mohamed et al. [107] demonstrated that females with intact ovaries showed an increase in bradycardic response to phenylephrine compared to ovariectomized females. It was reported that alcohol intake increases estradiol levels in humans and in rodents [108, 109], which might explain the predominance of vagal tone in females exposed to alcohol vapor and, consequently, may constitute a prominent adaptative mechanism in females that precludes the occurrence of changes in cardiovascular reactivity during stressful situations.

In addition to the evidence of female sex hormones, many recent studies indicated the positive role of male sex hormones (androgens) in cardiovascular protection $[81,110-114]$. Preclinical studies showed that 
testosterone induces endothelium-independent relaxation in isolated coronary artery and aorta, and also contributes to the vagal outflow, but not to the sympathetic outflow to the heart of male rats [111, 113, 115]. Indeed, Ward and Abdel-Rahman [116] demonstrated that orchiectomy or androgen receptor blockade attenuates baroreflex-mediated bradycardia in rats, suggesting that androgens (including testosterone) may enhance baroreflex bradycardia via the androgen receptor at the level of the baroreceptors at the aorta and carotid, the central nervous system, or the heart. Clinical trials showed that acute administration of testosterone in patients with chronic heart failure reduced peripheral vascular resistance, cardiac afterload, and increased cardiac index [117]. On the other hand, a negative correlation has been reported between ethanol consumption and testosterone release. Several studies have shown that ethanol is a testicular toxin and it causes deficiency in testosterone secretion and spermatogenesis [118-121]. For example, Maneesh and colleagues [118] observed that serum testosterone levels in alcoholics were negatively correlated with duration of alcohol abuse. Accordingly, studies in laboratory animals showed that high doses of alcohol decreased the testosterone concentrations in alcohol-preferring and non-preferring rats [122-124]. Taking these studies into account, we may suggest that ethanol-induced reduction on testosterone levels can disrupt the cardiovascular protection of androgens, contributing to the enhanced restraint-evoked sympathoexcitatory effect in males exposed to chronic alcohol vapor.

\section{Perspectives and significance}

Sexual dimorphism is an important factor affecting the cardiovascular response induced by both stress and chronic ethanol access. To the best of our knowledge, the findings reported here are the first to provide evidence related to the influence of sexual dimorphisms on the effect of chronic intermittent ethanol exposure on stress-evoked cardiovascular changes. Thus, the present study aimed to evaluate the effect of chronic ethanol vapor inhalation on blood pressure, HR, and tail skin temperature responses to acute stress, investigating differences between male and female rats.

Our data support the notion that exposure to chronic ethanol potentiates the cardiovascular reactivity to stressful stimuli in males but not in females and this opens doors for future work aiming at testing the mechanism underlying sex differences in cardiovascular responses to stress after a chronic exposure to ethanol. This evidence could be of great importance for implementing different strategies for treating cardiovascular diseases in abstinent alcoholic patients, considering the impact of biological sex and hormonal status in response to therapy.

\section{Conclusions}

The results reported here showed that chronic ethanol vapor inhalation enhanced both blood pressure and tachycardiac responses to acute restraint stress in male, but not female rats. Furthermore, a sex-related difference was observed in the cutaneous vasoconstriction response during stress, as males showed a decrease in cutaneous temperature that was sustained throughout the stress session, while females presented this reduction only at the beginning of restraint. Finally, more research is necessary to improve the understanding of the impact of prolonged ethanol exposure, and the influence of sexual dimorphisms, in other physiological and behavioral responses to stress.

\section{Acknowledgements}

The authors wish to thank São Paulo Research Foundation - FAPESP and National Council for Scientific and Technological Development - CNPq for supporting the research, Dr. Hugo Cogo-Moreira, MSc Fernanda Fiel Peres, and Dr. Cássio Morais Loss for statistical consultancy, and the Physic Institute of São Carlos - University of São Paulo where the study was developed.

\section{Authors' contributions}

Paula C. Bianchi, Carlos C. Crestani, Cleopatra S. Planeta, Rodrigo M. Leão, and Fabio C. Cruz conceived and designed the experiments. Paula C. Bianchi, Paola Palombo, Paulo E. C. Oliveira, Willian C. Ferreira, Lucas G. Souza, Rodrigo M. Leão, and Fabio C. Cruz performed the experiments. Paula C. Bianchi, Lucas G. Souza, Willian C. Ferreira, Sheila A. Engi, Carlos C. Crestani, and Fabio C. Cruz analyzed the data. Paula C. Bianchi, Carlos C. Crestani, and Fabio C. Cruz wrote the paper. All authors read, critically reviewed, and approved the final manuscript.

\section{Funding}

This work was supported in part by the Coordenação de Aperfeiçoamento de Pessoal de Nível Superior - Brasil (CAPES) - Finance Code 001, as well as by the São Paulo Research Foundation - FAPESP [2013/24896-2] and by the National Council for Scientific and Technological Development - CNPq [164060/2014-6]

Availability of data and materials

All data are available from the corresponding author upon request.

\section{Declarations}

Ethics approval and consent to participate

The study has been approved by the Ethical Committee for Use of Animal and Subjects of the Physic Institute of São Carlos-USP (approval\# 2014/01), which complies with Brazilian and international guidelines for animal use and welfare

Consent for publication

Not applicable.

\section{Competing interests}

The authors declare that they have no competing interests.

\section{Author details}

${ }^{1}$ Laboratory of Neuropsypharmacology, School of Pharmaceutical Sciences, São Paulo State University (UNESP), Rod. Araraquara-Jaú km 1, Araraquara, SP 14801-902, Brazil. Joint Graduate Program in Physiological Sciences UFSCar/ UNESP, Rod. Washington Luís km 235, São Carlos, SP 13565-905, Brazil.

${ }^{3}$ Laboratory of Pharmacology, Paulista Medicine School, Universidade Federal de São Paulo - UNIFESP, Leal Prado Building, Botucatu 862 Street, 04024-002, 
Vila Clementino, São Paulo, SP, Brazil. “Laboratory of Psychology, Psychology Department, Universidade Federal de São Carlos - UFSCar, Rod. Washington Luís km 235, São Carlos, SP 13565-905, Brazil. ${ }^{5}$ Joint Graduate Program in Pharmacology, Pharmacology and Molecular Biology Institute - INFAR, Três de Maio 100 Street, 04044-020, Vila Clementino, São Paulo, SP, Brazil. ${ }^{6}$ Biomedical Sciences Institute, Universidade Federal de Uberlândia, Uberlândia, Minas Gerais, Brazil.

\section{Received: 5 October 2020 Accepted: 1 March 2021 Published online: 16 March 2021}

\section{References}

1. World Health Organization. Global status report on alcohol and health 2018. Geneva: World Health Organization; 2018. https://apps.who.int/iris/handle/1 0665/274603. License: CC BY-NC-SA 3.0 IGO

2. Abdel-Rahman AA, Wooles WR. Ethanol-induced hypertension involves impairment of baroreceptors. Hypertension. 1987;10(1):67-73. https://doi. org/10.1161/01.HYP.10.1.67.

3. Abdel-Rahman AR, Dar MS, Wooles WR. Effect of chronic ethanol administration on arterial baroreceptor function and pressor and depressor responsiveness in rats. J Pharmacol Exp Ther. 1985;232:194-201.

4. Crestani CC, Lopes A, Scopinho AA, Ruginsk SG, Uchoa ET, Correa FMA, et al. Cardiovascular alterations at different stages of hypertension development during ethanol consumption: time-course of vascular and autonomic changes. Toxicol Appl Pharmacol 2014;280:245-255. https://doi. org/https://doi.org/10.1016/j.taap.2014.08.012,2.

5. Russ R, Abdel-Rahman AR, Wooles WR. Role of the sympathetic nervous system in ethanol-induced hypertension in rats. Alcohol. 1991;8(4):301-7. https://doi.org/10.1016/0741-8329(91)90433-W.

6. Lopes da Silva A, Ruginsk SG, Uchoa ET, Crestani CC, Scopinho AA, Correa FMA, de Martinis BS, Elias LLK, Resstel LB, Antunes-Rodrigues J Time-course of neuroendocrine changes and its correlation with hypertension induced by ethanol consumption. Alcohol Alcohol 2013;48:495-504. https://doi.org/ https://doi.org/10.1093/alcalc/agt040, 4.

7. Resstel LB, Tirapelli CR, Lanchote VL, Uyemura SA, de Oliveira AM, Corrêa FM. Chronic ethanol consumption alters cardiovascular functions in conscious rats. Life Sci. 2006;78(19):2179-87. https://doi.org/10.1016/j.lfs.2 005.09.021. Epub 2005 Nov 9. PMID: 16288925

8. Huether $\mathrm{G}$. The central adaptation syndrome: psychosocial stress as a trigger for adaptive modifications of brain structure and brain function. Prog Neurobiol 1996;48:569-612. https://doi.org/https://doi.org/10.1016/03 01-0082(96)00003-2, 6

9. Crestani CC. Emotional stress and cardiovascular complications in animal models: a review of the influence of stress type. Front Physiol 2016;7. https://doi.org/https://doi.org/10.3389/fphys.2016.00251.

10. Dampney RAL, Horiuchi J, McDowall LM. Hypothalamic mechanisms coordinating cardiorespiratory function during exercise and defensive behaviour. Auton Neurosci 2008;142:3-10. https://doi.org/https://doi.org/1 0.1016/j.autneu.2008.07.005, 1-2.

11. Ulrich-Lai YM, Herman JP. Neural regulation of endocrine and autonomic stress responses. Nat Rev Neurosci 2009;10:397-409. https://doi.orge/https:// doi.org/10.1038/nrn2647, 6.

12. Buynitsky T, Mostofsky DI. Restraint stress in biobehavioral research: recent developments. Neurosci Biobehav Rev 2009:33:1089-1098. https://doi.org/ https://doi.org/10.1016/j.neubiorev.2009.05.004, 7 .

13. Campos AC, Fogaca M V., Aguiar DC, Guimaraes FS. Animal models of anxiety disorders and stress. Rev Bras Psiquiatr 2013;35:S101-S111. https:// doi.org/https://doi.org/10.1590/1516-4446-2013-1139, suppl 2.

14. Bali A, Jaggi AS. Preclinical experimental stress studies: protocols, assessment and comparison. Eur J Pharmacol 2015;746:282-292. https://doi. org/https://doi.org/10.1016/j.ejphar.2014.10.017.

15. Crestani CC, Tavares RF, Alves FHF, Resstel LBM, Correa FMA. Effect of acute restraint stress on the tachycardiac and bradycardiac responses of the baroreflex in rats. Stress 2010;13:61-72. https://doi.org/https://doi.org/10.31 09/10253890902927950, 1.

16. Busnardo C, Alves FHF, Crestani CC, Scopinho AA, Resstel LBM, Correa FMA. Paraventricular nucleus of the hypothalamus glutamate neurotransmission modulates autonomic, neuroendocrine and behavioral responses to acute restraint stress in rats. Eur Neuropsychopharmacol 2013;23:1611-1622. https://doi.org/https://doi. org/10.1016/j.euroneuro.2012.11.002, 11.
17. Herborn KA, Graves JL, Jerem P, Evans NP, Nager R, McCafferty DJ, et al. Skin temperature reveals the intensity of acute stress. Physiol Behav 2015;152: 225-230. https://doi.org/https://doi.org/10.1016/.jphysbeh.2015.09.032, Pt A.

18. Vianna DML, Carrive P. Changes in cutaneous and body temperature during and after conditioned fear to context in the rat. Eur $\mathrm{J}$ Neurosci 2005;21:2505-2512. https://doi.org/https://doi.org/10.1111/j.1460-9568.2 005.04073.x, 9.

19. Gomes-de-Souza L, Oliveira LA, Benini R, Rodella P, Costa-Ferreira W, Crestani CC. Involvement of endocannabinoid neurotransmission in the bed nucleus of stria terminalis in cardiovascular responses to acute restraint stress in rats. Br J Pharmacol 2016:2833-2844. https://doi.org/https://doi. org/10.1111/bph.13560, 173, 19.

20. Reckelhoff JF. Gender differences in the regulation of blood pressure. Hypertension 2001;37:1199-1208. https://doi.org/https://doi.org/10.1161/01. HYP.37.5.1199, 5.

21. Bianchi PC, Costa Ferreira W, Antonagi Engi S, Palombo P, Carneiro de Oliveira PE, Gomes de Souza L, Crestani CC, Costa JL, da Silva Planeta C, Molini Leão R, Cardoso Cruz F Prolonged exposure to alcohol vapor causes change in cardiovascular function in female but not in male rats. Alcohol Clin Exp Res 2019;43. https://doi.org/https://doi.org/10.1111/acer.14035, Prolonged Exposure to Alcohol Vapor Causes Change in Cardiovascular Function in Female but not in Male Rats.

22. Anishchenko TG, Glushkovskaya-Semyachkina O V., Berdnikova VA, Sindyakova TA. Sex-related differences in cardiovascular stress reactivity in healthy and hypertensive rats. Bull Exp Biol Med 2007;143:178-181. https:// doi.org/https://doi.org/10.1007/s10517-007-0043-9, 2.

23. Azar T, Sharp J, Lawson D. Stress-like cardiovascular responses to common procedures in male versus female spontaneously hypertensive rats. Contemp Top Lab Anim Sci. 2005;44(3):25-30.

24. Hammer JH, Parent MC, Spiker DA, World Health Organization. Global status report on alcohol and health 2018. vol. 65. 2018. https://doi.org/https://doi. org/10.1037/cou0000248.

25. Vieira JO, Duarte JO, Costa-Ferreira W, Morais-Silva G, Marin MT, Crestani CC. Sex differences in cardiovascular, neuroendocrine and behavioral changes evoked by chronic stressors in rats. Prog Neuro-Psychopharmacol Biol Psychiatry 2018;81:426-437. https://doi.org/https://doi.org/10.1016/j.pnpbp.2 017.08.014.

26. Anishchenko TG, Mamontov BN, Shorina LN. Sex differences in the cholinergic status of albino rats. Bull Exp Biol Med 1992;114:1408-1411. https://doi.org/https://doi.org/10.1007/BF00841578, 4.

27. Leinwand LA. Sex is a potent modifier of the cardiovascular system. J Clin Invest 2003;112:302-307. https://doi.org/https://doi.org/10.1172/JCl1 $9429,3$.

28. Matthews KA, Stoney CM. Influences of sex and age on cardiovascular responses during stress. Psychosom Med 1988;50:46-56. https://doi.org/ https://doi.org/10.1097/00006842-198801000-00006, 1.

29. Corrao G, Bagnardi V, Zambon A, Arico S. Exploring the dose-response relationship between alcohol consumption and the risk of several alcoholrelated conditions: a meta-analysis. Addiction. 1999;94(10):1551-73. https:// doi.org/10.1046/j.1360-0443.1999.9410155111.x.

30. Corrao G, Bagnardi V, Zambon A, La Vecchia C. A meta-analysis of alcohol consumption and the risk of 15 diseases. Prev Med (Baltim) 2004;38:613619. https://doi.org/https://doi.org/10.1016/j.ypmed.2003.11.027, 5.

31. Puddey IB, Rakic V, Dimmitt SB, Beilin LJ. Influence of pattern of drinking on cardiovascular disease and cardiovascular risk factors-a review. Addiction. 1999;94(5):649-63. https://doi.org/10.1046/j.1360-0443.1999.9456493.x.

32. Sesso HD, Cook NR, Buring JE, Manson JE, Gaziano JM. Alcohol consumption and the risk of hypertension in women and men Hypertension. 2008;51(4):1080-7. https://doi.org/10.1161/HYPERTENSIONA HA.107.104968. Epub 2008 Feb 7. PMID: 18259032.

33. Taylor B, Irving HM, Baliunas D, Roerecke M, Patra J, Mohapatra S, Rehm J Alcohol and hypertension: gender differences in dose-response relationships determined through systematic review and meta-analysis. Addiction 2009;104:1981-1990. https://doi.org/https://doi.org/10.1111/j.13 60-0443.2009.02694.x, 12

34. Wakabayashi I. Influence of gender on the association of alcohol drinking with blood pressure 2017;21. https:/doi.org/https://doi.org/10.1038/ajh.2008.299.

35. El-Mas MM, Abdel-Rahman AA. An association between the estrogendependent hypotensive effect of ethanol and an elevated brainstem c-jun mRNA in female rats. Brain Res. 2001;912(1):79-88. https://doi.org/10.1016/ s0006-8993(01)02727-5. PMID: 11520495. 
36. El-mas MM, Abdel-rahman AA. Exacerbation of myocardial dysfunction and autonomic imbalance contributes to the estrogen-dependent chronic hypotensive effect of ethanol in female rats. Eur J Pharmacol 2012;679:95100. https://doi.org/https://doi.org/10.1016/j.ejphar.2012.01.008, 1-3.

37. El-Mas MM, Abdel-Rahman AA. Ovariectomy alters the chronic hemodynamic and sympathetic effects of ethanol in radiotelemetered female rats. Clin Exp Hypertens. 2000;22(1):109-26. https://doi.org/10.1081/ ceh-100100066. PMID: 10685729.

38. El-Mas MM, Fan M, Abdel-Rahman AA. Upregulation of cardiac NOS due to endotoxemia and vagal overactivity contributes to the hypotensive effect of chronic ethanol in female rats. Eur J Pharmacol 2011;650:317-323. https:// doi.org/https://doi.org/10.1016/j.ejphar.2010.10.032, 1

39. Sparrow MG, Roggendorf $H$, Vogel WH. Effect of ethanol on heart rate and blood pressure in nonstressed and stressed rats. Life Sci 1987;40:2551-2559. https://doi.org/https://doi.org/10.1016/0024-3205(87)90078-6, 26.

40. Abdel-Rahman a a. Gender difference in baroreflex-mediated bradycardia in young rats: role of cardiac sympathetic and parasympathetic components. Can J Physiol Pharmacol 1999;77:358-366. https://doi.org/https://doi.org/1 0.1139/cjpp-77-5-358, 5.

41. Ajayi A., Hercule H, Cory J, Hayes B., Oyekan A. Gender difference in vascular and platelet reactivity to thromboxane A2-mimetic U46619 and to endothelial dependent vasodilation in Zucker fatty (hypertensive, hyperinsulinemic) diabetic rats. Diabetes Res Clin Pract 2003;59:11-24. https://doi.org/https://doi.org/10.1016/S0168-8227(02)00180-8, 1.

42. Blizard DA, Peterson WN, Iskandar SS, Shihabi ZK, Adams N. The effect of a high salt diet and gender on blood pressure, urinary protein excretion and renal pathology in Shr rats. Clin Exp Hypertens Part A Theory Pract 1991;13:687-697. https://doi.org/https://doi.org/10.3109/1 0641969109042072, 5

43. Khan IY, Taylor PD, Dekou V, Seed PT, Lakasing L, Graham D, Dominiczak AF, Hanson MA, Poston L Gender-linked hypertension in offspring of lard-fed pregnant rats. Hypertension 2003;41:168-175. https://doi.org/https://doi. org/10.1161/01.HYP.0000047511.97879.FC, 1.

44. Weinstock M, Razin M, Schorer-apelbaum D, Men D, McCarty R. Gender differences in sympathoadrenal activity in rats at rest and in response to footshock stress. Int J Dev Neurosci 1998;16:289-295. https://doi.org/https:// doi.org/10.1016/S0736-5748(98)00021-5, 3-4.

45. Taylor TA, Gariepy CE, Pollock DM, Pollock JS. Gender differences in ET and NOS systems in ET B receptor-deficient rats. Hypertension 2003;41:657-662. https://doi.org/https://doi.org/10.1161/01.HYP.0000048193.85814.78, 3.

46. Tostes RC, Nigro D, Fortes ZB, Carvalho MHC. Effects of estrogen on the vascular system. Braz J Med Biol Res 2003;36:1143-1158. https://doi.org/ https://doi.org/10.1590/50100-879X2003000900002, 9.

47. Gilpin NW, Richardson HN, Cole M, Koob GF. Vapor inhalation of alcohol in rats. Curr Protoc Neurosci 2008. https://doi.org/https://doi.org/10.1002/04 71142301.ns0929s44, 44, 1.

48. Gilpin NW, Smith AD, Cole M, Weiss F, Koob GF, Richardson HN. Operant behavior and alcohol levels in blood and brain of alcohol-dependent rats. Alcohol Clin Exp Res 2009;33:2113-2123. https://doi.org/https://doi.org/1 0.1111/j.1530-0277.2009.01051.x, 12

49. Vendruscolo LF, Roberts AJ. Operant alcohol self-administration in dependent rats: focus on the vapor model. Alcohol 2014;48:277-286. https://doi.org/10.1016/j.alcohol.2013.08.006, 3.

50. Roberts DCS, Morgan D, Liu Y. How to make a rat addicted to cocaine. Prog Neuro-Psychopharmacology Biol Psychiatry 2007;31:1614-1624. https://doi. org/https://doi.org/10.1016/j.pnpbp.2007.08.028, 8.

51. Roberts AJ, Cole M, Koob GF. Intra-amygdala muscimol decreases operant ethanol self-administration in dependent rats. Alcohol Clin Exp Res. 1996; 20(7):1289-98. https://doi.org/10.1111/j.1530-0277.1996.tb01125.x.

52. Meinhardt MW, Sommer WH. Postdependent state in rats as a model for medication development in alcoholism. Addict Biol 2015;20:1-21. https:// doi.org/https://doi.org/10.1111/adb.12187, 1.

53. Leão RM, Cruz FC, Vendruscolo LF, de Guglielmo G, Logrip ML, Planeta CS, Hope BT, Koob GF, George O Chronic nicotine activates stress/reward-related brain regions and facilitates the transition to compulsive alcohol drinking. J Neurosci 2015;35: 6241-6253. https:/doi.org/https:/doi.org/10.1523/JNEUROSCI.3302-14.2015, 15.

54. Cruz FC, Engi SA, Leão RM, Planeta CS, Crestani CC. Influence of the single or combined administration of cocaine and testosterone in autonomic and neuroendocrine responses to acute restraint stress. J Psychopharmacol 2012;26:1366-1374. https://doi.org/https://doi.org/10.11 77/0269881112453210, 10
55. Oliveira LA, Gomes-de-Souza L, Benini R, Crestani CC. Control of cardiovascular responses to stress by CRF in the bed nucleus of stria terminalis is mediated by local NMDA/nNOS/sGC/PKG signaling. Psychoneuroendocrinology 2018;89:168-176. https://doi.org/https://doi. org/10.1016/j.psyneuen.2018.01.010.

56. Benini R, Oliveira LA, Gomes-de-Souza L, Rodrigues B, Crestani CC. Habituation of the cardiovascular response to restraint stress is inhibited by exposure to other stressor stimuli and exercise training. J Exp Biol 2020;223: jeb219501. https://doi.org/https://doi.org/10.1242/jeb.219501.

57. Benini R, Oliveira LA, Gomes-de-Souza L, Crestani CC. Habituation of the cardiovascular responses to restraint stress in male rats: influence of length, frequency and number of aversive sessions. Stress 2019;22:151-161. https:// doi.org/https://doi.org/10.1080/10253890.2018.1532992, 1.

58. Ma Y, Mazumdar M, Memtsoudis SG. Beyond repeated-measures analysis of variance. Reg Anesth Pain Med 2012;37:99-105. https://doi.org/https://doi. org/10.1097/AAP.0b013e31823ebc74, 1.

59. Bianchi PC, Carneiro de Oliveira PE, Palombo P, Leão RM, Cogo-Moreira H, Planeta CDS, et al. Functional inactivation of the orbitofrontal cortex disrupts context-induced reinstatement of alcohol seeking in rats. Drug Alcohol Depend 2018;186. https://doi.org/https://doi.org/10.1016/j.druga Icdep.2017.12.045, 186, 112.

60. Gilpin NW, Koob GF. Neurobiology of alcohol dependence: focus on motivational mechanisms. Alcohol Res Health 2008;31:185-195. https://doi. org/https://doi.org/10.1016/j.biotechadv.2011.08.021.Secreted.

61. Koob GF. Alcohol use disorders: tracts, twins, and trajectories. Am J Psychiatry 2015;172:499-501. https://doi.org/https://doi.org/10.1176/appi.a jp.2015.15020240, 6

62. Kwako LE, Momenan R, Litten RZ, Koob GF, Goldman D. Addictions neuroclinical assessment: a neuroscience-based framework for addictive disorders. Biol Psychiatry 2016;80:179-189. https://doi.org/https://doi.org/1 0.1016/j.biopsych.2015.10.024, 3.

63. O'Dell LE, Roberts AJ, Smith RT, Koob GF. Enhanced alcohol selfadministration after intermittent versus continuous alcohol vapor exposure. Alcohol Clin Exp Res 2004;28:1676-1682. https://doi.org/https://doi.org/10.1 097/01.ALC.0000145781.11923.4E, 11.

64. McCool BA, Chappell AM. Chronic intermittent ethanol inhalation increases ethanol self-administration in both C57BL/6J and DBA/2J mice. Alcohol 2015;49:111-120. https://doi.org/https://doi.org/10.1016/j.alcohol.2015.01.003 2.

65. Lopez MF, Becker HC. Effect of pattern and number of chronic ethanol exposures on subsequent voluntary ethanol intake in C57BL/6J mice. Psychopharmacology (Berl) 2005;181:688-696. https://doi.org/https://doi. org/10.1007/s00213-005-0026-3, 4.

66. Lopez MF, Griffin WC, Melendez Rl, Becker HC. Repeated cycles of chronic intermittent ethanol exposure leads to the development of tolerance to aversive effects of ethanol in C57BL/6J mice. Alcohol Clin Exp Res 2012;36: 1180-1187. https://doi.org/https://doi.org/10.1111/j.1530-0277.2011.01717.x, 7.

67. Chan TC, Wall RA, Sutter MC. Chronic ethanol consumption, stress, and hypertension. Hypertension 1985;7:519-524. https://doi.org/https://doi.org/1 $0.1161 / 01 . H Y P 7.4 .519,4$

68. Chan TCK, Sutter MC. Ethanol consumption and blood pressure. Life Sci 1983;33:1965-1973. https://doi.org/https://doi.org/10.1016/0024-3205(83 990734-8, 20.

69. Engi SA, Planeta CS, Crestani CC. Effect of Voluntary Ethanol Consumption Combined with Testosterone Treatment on Cardiovascular Function in Rats: Influence of Exercise Training. PLoS One. 2016;11(1):e0146974. https://doi. org/10.1371/journal.pone.0146974.

70. El-Mas MM, Fan M, Abdel-Rahman AA. Endotoxemia-mediated induction of cardiac inducible nitric-oxide synthase expression accounts for the hypotensive effect of ethanol in female rats. J Pharmacol Exp Ther 2008;324: 368-375. https://doi.org/https://doi.org/10.1124/jpet.107.127498, 1.

71. El-Mas MM, Fan M, Abdel-Rahman AA. Facilitation of myocardial PI3K/Akt/ nNOS signaling contributes to ethanol-evoked hypotension in female rats. Alcohol Clin Exp Res 2009;33:1158-1168. https://doi.org/https://doi.org/1 0.1111/j.1530-0277.2009.00939.x, 7.

72. Duan J, Esberg LB, Ye G, Borgerding AJ, Ren BH, Aberle NS, Epstein PN, Ren $J$. Influence of gender on ethanol-induced ventricular myocyte contractile depression in transgenic mice with cardiac overexpression of alcohol dehydrogenase. Comp Biochem Physiol A Mol Integr Physiol. 2003;134(3): 607-14. https://doi.org/10.1016/s1095-6433(02)00347-1. PMID: 12600669. 
73. Takase B, Kurita A, Noritake M, Uehata A, Maruyama T, Nagayoshi H, Nishioka T, Mizuno K, Nakamura H Heart rate variability in patients with diabetes mellitus, ischemic heart disease, and congestive heart failure. J Electrocardiol 1992;25:79-88. https://doi.org/https://doi.org/10.1016/00220736(92)90112-D, 2.

74. Tsuji H, Larson MG, Venditti FJ, Manders ES, Evans JC, Feldman CL, Levy D. Impact of reduced heart rate variability on risk for cardiac events. The Framingham heart study. Circulation. 1996;94(11):2850-5. https://doi.org/ 8941112. https://doi.org/10.1161/01.CIR.94.11.2850.

75. Crestani CC, Alves FHF, Busnardo C, Resstel LBM, Correa FMA. N-Methyl-daspartate glutamate receptors in the hypothalamic paraventricular nucleus modulate cardiac component of the baroreflex in unanesthetized rats. Neurosci Res 2010;67:317-326. https://doi.org/https://doi.org/10.1016/j. neures.2010.05.001, 4.

76. Zhang Z-Q, Julien C, Barrès C. Baroreceptor modulation of regional haemodynamic responses to acute stress in rat. J Auton Nerv Syst 1996;60: 23-30. https://doi.org/https://doi.org/10.1016/0165-1838(96)00023-9, 1-2.

77. Carrive P. Dual activation of cardiac sympathetic and parasympathetic components during conditioned fear to context in the rat. Clin Exp Pharmacol Physiol 2006;33:1251-1254. https://doi.org/https://doi.org/1 0.1111/j.1440-1681.2006.04519.x, 12

78. Zhen LI, Krause DN, Doolen S, Piper Duckles SUE. Ovariectomy eliminates sex differences in rat tail artery response to adrenergic nerve stimulation. Am J Physiol Hear Circ Physiol 1997;41. https://doi.org/https://doi.org/10.11 52/ajpheart.1997.272.4.h1819, 4, H1819, H1825.

79. Mendelsohn ME. Protective effects of estrogen on the cardiovascular system. Am J Cardiol 2002:89:12-17. https://doi.org/https://doi.org/10.1016/ S0002-9149(02)02405-0, 12

80. Hodgin JB, Knowles JW, Kim HS, Smithies O, Maeda N. Interactions between endothelial nitric oxide synthase and sex hormones in vascular protection in mice. J Clin Invest 2002;109:541-548. https://doi.org/https://doi.org/10.11 72/JCI0214066, 4.

81. Boese AC, Kim SC, Yin K-J, Lee J-P, Hamblin MH. Sex differences in vascular physiology and pathophysiology: estrogen and androgen signaling in health and disease. Am J Physiol Circ Physiol 2017;313:H524-H545. https:// doi.org/https://doi.org/10.1152/ajpheart.00217.2016, 3.

82. Baudrie V, Tulen JHM, Blanc J, Elghozi J-L. Autonomic components of the cardiovascular responses to an acoustic startle stimulus in rats. J Auton Pharmacol 1997;17:303-309. https://doi.org/https://doi.org/10.1046/j.1365-2 680.1997.00465.x, 5 .

83. dos Reis DG, Fortaleza EAT, Tavares RF, Corrêa FMA. Role of the autonomic nervous system and baroreflex in stress-evoked cardiovascular responses in rats. Stress 2014;17:362-372. https://doi.org/https://doi.org/10.3109/10253 890.2014.930429, 4.

84. Tirapelli CR, Leone AFC, Coelho EB, Resstel LBM, Corrêa FMA, Lanchote VL, Uyemura SA, Padovan CM, de Oliveira AM Effect of ethanol consumption on blood pressure and rat mesenteric arterial bed, aorta and carotid responsiveness. J Pharm Pharmacol 2007;59:985-993. https://doi.org/https:// doi.org/10.1211/jpp.59.7.0011, 7.

85. Resstel LBM, Scopinho AA, Lopes da Silva A, Rodrigues JA, Correa FMA. Increased circulating vasopressin may account for ethanol-induced hypertension in rats. Am J Hypertens 2008;21:930-935. https://doi.org/ https://doi.org/10.1038/ajh.2008.189, 8.

86. Vasconcelos SMM, Cavalcante RA, Aguiar LMV, Sousa FCF, Fonteles MMF, Viana GSB. Effects of chronic ethanol treatment on monoamine levels in rat hippocampus and striatum. Brazilian J Med Biol Res 2004;37:1839-1846. https://doi.org/https://doi.org/10.1590/S0100-879X2004001200009, 12.

87. Ladipo C, Adigun S, Nwaigwe C, Adegunloye B. Chronic ethanol consumption alters vascular smooth muscle responses in rats. Clin Exp Pharmacol Physiol 2002;29:707-709. https://doi.org/https://doi.org/10.1046/ j.1440-1681.2002.03721.x, 8.

88. Marchi KC, Muniz JJ, Tirapelli CR. Hypertension and chronic ethanol consumption: what do we know after a century of study? World J Cardiol 2014;6:283-294. https://doi.org/https://doi.org/10.4330/wjc.v6.15.283, 5.

89. Stewart CW, Kennedy RH. Effects of chronic ethanol consumption on aortic constriction in male and female rats. Eur J Pharmacol 1999;366:55-60. https://doi.org/https://doi.org/10.1016/S0014-2999(98)00900-5, 1.

90. Tirapelli CR, Al-Khoury J, Bkaily G, D'Orléans-Juste P, Lanchote VL, Uyemura $S A$, et al. Chronic ethanol consumption enhances phenylephrine-induced contraction in the isolated rat aorta. J Pharmacol Exp Ther 2006;316:233241. https://doi.org/https://doi.org/10.1124/jpet.105.092999, 1.
91. Liu J, Tian Z, Gao B, Kunos G. Dose-dependent activation of antiapoptotic and proapoptotic pathways by ethanol treatment in human vascular endothelial cells. J Biol Chem 2002;277:20927-20933. https://doi.org/https:// doi.org/10.1074/jbc.M110712200, 23.

92. Toda N, Ayajiki K. Vascular actions of nitric oxide as affected by exposure to alcohol. Alcohol Alcohol 2010;45:347-355. https://doi.org/https://doi.org/1 0.1093/alcalc/agq028, 4.

93. Randin D, Vollenweider P, Tappy L, Jéquier E, Nicod P, Scherrer U. Suppression of alcohol-induced hypertension by dexamethasone. N Engl J Med 1995;332:1733-1738. https://doi.org/https://doi.org/10.1056/NEJM1 99506293322601, 26.

94. Becker HC. Effects of alcohol dependence and withdrawal on stress responsiveness and alcohol consumption. Alcohol Res. 2012;34(4):448-58.

95. Rasmussen DD, Wilkinson CW, Raskind MA. Chronic daily ethanol and withdrawal: 6. Effects on rat sympathoadrenal activity during "abstinence". Alcohol 2006;38:173-177. https://doi.org/https://doi.org/10.1016/j.alcohol.2 006.06.007, 3 .

96. Heilig M, Egli M, Crabbe JC, Becker HC. Acute withdrawal, protracted abstinence and negative affect in alcoholism: are they linked? Addict Biol 2010;15:169-184. https://doi.org/https://doi.org/10.1111/j.1369-1600.2009.001 94.x, 2.

97. Richardson HN, Lee SY, O'Dell LE, Koob GF, Rivier CL. Alcohol selfadministration acutely stimulates the hypothalamic-pituitary-adrenal axis, but alcohol dependence leads to a dampened neuroendocrine state. Eur J Neurosci 2008;28:1641-1653. https://doi.org/https://doi.org/10.1111/j.14609568.2008.06455.x, 8

98. Sommer WH, Rimondini R, Hansson AC, Hipskind PA, Gehlert DR, Barr CS, Heilig MA Upregulation of voluntary alcohol intake, behavioral sensitivity to stress, and amygdala Crhr1 expression following a history of dependence. Biol Psychiatry 2008;63:139-145. https://doi.org/https://doi.org/10.1016/j. biopsych.2007.01.010, 2.

99. Valdez GR, Roberts AJ, Chan K, Davis H, Brennan M, Zorrilla EP, Koob GF Increased ethanol self-administration and anxiety-like behavior during acute ethanol withdrawal and protracted abstinence: regulation by corticotropinreleasing factor. Alcohol Clin Exp Res 2002;26:1494-1501. https://doi.org/ https://doi.org/10.1097/01.ALC.0000033120.51856.F0, 10.

100. Valdez GR, Zorrilla EP, Roberts AJ, Koob GF. High-priority communication I Antagonism of corticotropin-releasing factor attenuates the enhanced responsiveness to stress observed during protracted ethanol abstinence. Alcohol 2003;29:55-60. https://doi.org/https://doi.org/10.1016/S0741-8329(03 )00020-X, 2.

101. King AC, Bernardy NC, Parsons OA, Lovallo WR. Hemodynamic alterations in alcohol-related transitory hypertension. Alcohol 1996;13:387-393. https:/doi. org/https://doi.org/10.1016/0741-8329(96)00029-8, 4.

102. Bernardy NC, King AC, Lovallo WR. Cardiovascular responses to physical and psychological stress in female alcoholics with transitory hypertension after early abstinence. Alcohol Clin Exp Res 2003;27:1489-1498. https://doi.org/ https://doi.org/10.1097/01.ALC.0000085587.00498.38, 9.

103. Kähkönen S. Mechanisms of cardiovascular dysregulation during alcohol withdrawal. Prog Neuro-Psychopharmacology Biol Psychiatry 2004;28:937941. https://doi.org/https://doi.org/10.1016/j.pnpbp.2004.05.039, 6.

104. Ibrahim BM, Fan M, Abdel-Rahman AA. Oxidative stress and autonomic dysregulation contribute to the acute time-dependent myocardial depressant effect of ethanol in conscious female rats. Alcohol Clin Exp Res. 2014;38(5):1205-15. https://doi.org/10.1111/acer.12363. PMID: 24754626; PMCID: PMC3999510.

105. El-Mas MM, Abdel-Rahman AA. Endothelial and neuronal nitric oxide synthases variably modulate the oestrogen-mediated control of blood pressure and cardiovascular autonomic control. Clin Exp Pharmacol Physiol 2014;41:246-254. https://doi.org/https://doi.org/10.1111/1440-1 681.12207, 3.

106. Varga K, Gantenberg NS, Kunos G. Endogenous gamma-aminobutyric acid (GABA) mediates ethanol inhibition of vagally mediated reflex bradycardia elicited from aortic baroreceptors. J Pharmacol Exp Ther. 1994;268(2):105762. https://doi.org/WOS:A1994MY58600073.

107. Mohamed MK, El-Mas MM, Abdel-Rahman a a. Estrogen enhancement of baroreflex sensitivity is centrally mediated. Am J Physiol 1999;276:R1030R1037. https://doi.org/CCC:000079548600015, 4, DOI: https://doi.org/10.11 52/ajpregu.1999.276.4.R1030.

108. Emanuele NV, LaPaglia N, Steiner J, Kirsteins L, Emanuele MA. Effect of chronic ethanol exposure on female rat reproductive cyclicity and hormone 
secretion. Alcohol Clin Exp Res. 2001;25(7):1025-9. https://doi.org/10.1111/j.1 530-0277.2001.tb02312.x.

109. Muti P, Trevisan M, Micheli A, Krogh V, Bolelli G, Sciajno R, et al. Alcohol consumption and total estradiol in premenopausal women. Cancer Epidemiol Biomarkers Prev. 1998;7:189-93.

110. Chistiakov D, Myasoedova V, Melnichenko A, Grechko A, Orekhov A. Role of androgens in cardiovascular pathology. Vasc Health Risk Manag 2018; Volume 14:283-290. https://doi.org/https://doi.org/10.2147/NHRM.S173259.

111. El-Mas MM, Afify EA, Mohy El-Din MM, Omar AG, Sharabi FM. Testosterone facilitates the baroreceptor control of reflex bradycardia: role of cardiac sympathetic and parasympathetic components. J Cardiovasc Pharmacol 2001;38:754-763. https://doi.org/https://doi.org/10.1097/00005344-200111 000-00012, 5.

112. Crews F, He J, Hodge C. Adolescent cortical development: a critical period of vulnerability for addiction. Pharmacol Biochem Behav 2007;86:189-199. https://doi.org/https://doi.org/10.1016/j.pbb.2006.12.001, 2.

113. Yue P, Chatterjee K, Beale C, Poole-Wilson PA, Collins P. Testosterone relaxes rabbit coronary arteries and aorta. Circulation 1995;91:1154-1160. https:// doi.org/https://doi.org/10.1161/01.CIR.91.4.1154, 4.

114. Nettleship JE, Jones RD, Channer KS, Jones TH. Testosterone and coronary artery disease. Adv. Manag. Testosterone Defic., Basel: KARGER; 2008, p. 91107. https://doi.org/https://doi.org/10.1159/000176047.

115. Crews JK, Khalil RA. Antagonistic Effects of 17ß-estradiol, progesterone, and testosterone on $\mathrm{Ca} 2+$ entry mechanisms of coronary vasoconstriction. Arterioscler Thromb Vasc Biol 1999;19:1034-1040. https://doi.org/https://doi. org/10.1161/01.ATV.19.4.1034, 4

116. Ward GR, Abdel-Rahman AA. Orchiectomy or androgen receptor blockade attenuates baroreflex-mediated bradycardia in conscious rats. BMC Pharmacol 2006;6:2. https://doi.org/https://doi.org/10.1186/1471-2210-6-2, 1.

117. Pugh P. Acute haemodynamic effects of testosterone in men with chronic heart failure. Eur Heart J 2003;24:909-915. https://doi.org/https://doi.org/10.1 016/50195-668X(03)00083-6, 10.

118. Maneesh M, Dutta S, Chakrabarti A, Vasudevan DM. Alcohol abuse-duration dependent decrease in plasma testosterone and antioxidants in males. Indian J Physiol Pharmacol. 2006;50(3):291-6.

119. Maneesh M, Dutta S, Chakrabarti A, Vasudevan DM. Experimental therapeutic intervention with alpha tocopherol in ethanol induced testicular injuries in rats. Indian J Clin Biochem 2007;22:138-142. https://doi.org/ https://doi.org/10.1007/BF02912898, 1.

120. La Vignera S, Condorelli RA, Balercia G, Vicari E, Calogero AE. Does alcohol have any effect on male reproductive function? A review of literature. Asian J Androl 2013;15:221-225. https://doi.org/https://doi.org/10.1038/aja.2012.118, 2.

121. Sermondade N, Elloumi H, Berthaut I, Mathieu E, Delarouzière V, Ravel C, Mandelbaum J Progressive alcohol-induced sperm alterations leading to spermatogenic arrest, which was reversed after alcohol withdrawal. Reprod Biomed Online 2010;20:324-327. https://doi.org/https://doi.org/10.1016/j. rbmo.2009.12.003, 3.

122. Apter SJ, Eriksson CJP. The effect of alcohol on testosterone concentrations in alcohol-preferring and non-preferring rat lines. Alcohol Clin Exp Res 2003;27: 1190-1193. https:/doi.org/https:/doi.org/10.1097/01.ALC.0000075832.83254.81, 7.

123. Cicero TJ, Badger TM. Effects of alcohol on the hypothalamic-pituitarygonadal axis in the male rat. J Pharmacol Exp Ther. 1977;201(2):427-33.

124. Eriksson CJP, Widenius T V, Ylikahri RH, Härkönen M, Leinonen P. Inhibition of testosterone biosynthesis by ethanol. Relation to hepatic and testicular acetaldehyde, ketone bodies and cytosolic redox state in rats. Biochem J 1983;210:29-36. https://doi.org/https://doi.org/10.1042/bj2100029, 1.

\section{Publisher's Note}

Springer Nature remains neutral with regard to jurisdictional claims in published maps and institutional affiliations.

Ready to submit your research? Choose BMC and benefit from:

- fast, convenient online submission

- thorough peer review by experienced researchers in your field

- rapid publication on acceptance

- support for research data, including large and complex data types

- gold Open Access which fosters wider collaboration and increased citations

- maximum visibility for your research: over $100 \mathrm{M}$ website views per year

At BMC, research is always in progress.

Learn more biomedcentral.com/submissions 